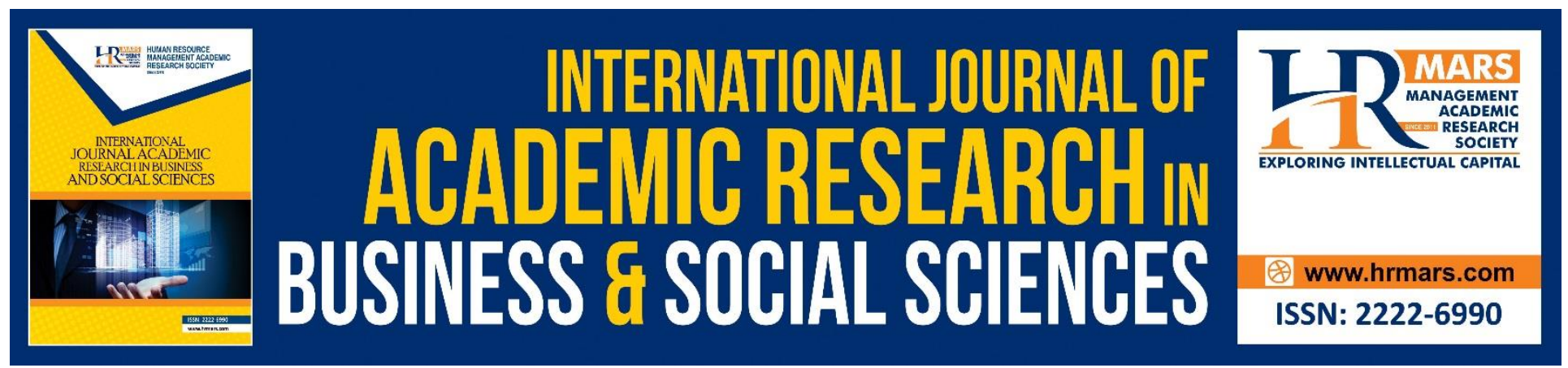

\title{
Post Covid-19 Online Business Strategies by Small-scale Entrepreneurs in Malaysia
}

Siti Masayu Rosliah Abdul Rashid, Fatimah Hassan and Kurshiah Ahmad

To Link this Article: http://dx.doi.org/10.6007/IJARBSS/v10-i9/7635

DOI:10.6007/IJARBSS/v10-i9/7635

Received: 08 June 2020, Revised: 11 July 2020, Accepted: 15 August 2020

Published Online: 28 September 2020

In-Text Citation: (Abdul Rashid, Hassan, \& Ahmad, 2020)

To Cite this Article: Abdul Rashid, S. M. R., Hassan, F., \& Ahmad, K. (2020). Post Covid-19 Online Business

Strategies by Small-scale Entrepreneurs in Malaysia. International Journal of Academic Research in Business and Social Sciences. 10(9), 564-571.

Copyright: (C) 2020 The Author(s)

Published by Human Resource Management Academic Research Society (www.hrmars.com)

This article is published under the Creative Commons Attribution (CC BY 4.0) license. Anyone may reproduce, distribute, translate and create derivative works of this article (for both commercial and non-commercial purposes), subject to full attribution to the original publication and authors. The full terms of this license may be seen at: http://creativecommons.org/licences/by/4.0/legalcode

Vol. 10, No. 9, 2020, Pg. 564 - 571

http://hrmars.com/index.php/pages/detail/IJARBSS

JOURNAL HOMEPAGE

Full Terms \& Conditions of access and use can be found at http://hrmars.com/index.php/pages/detail/publication-ethics 


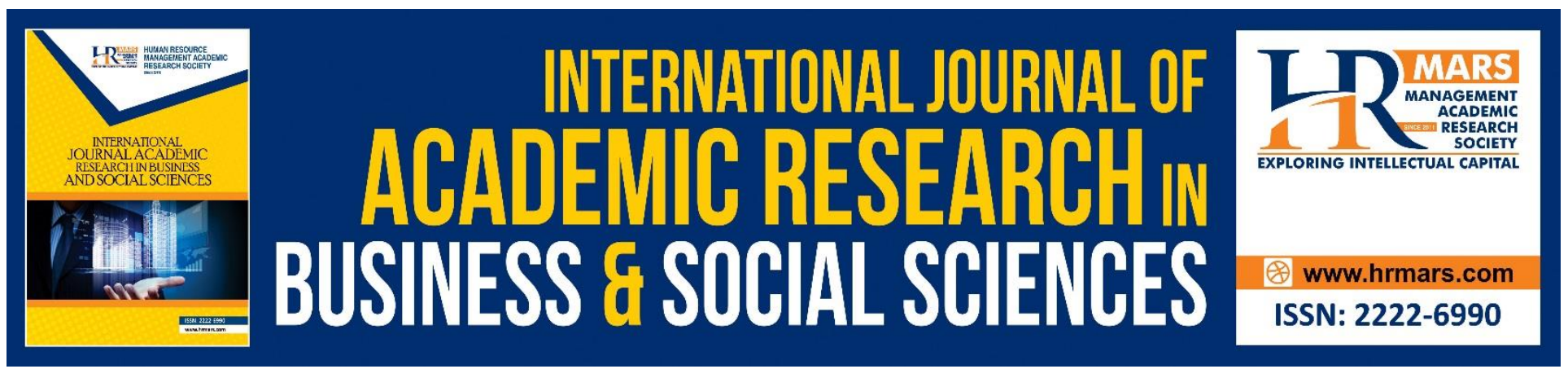

\title{
Post Covid-19 Online Business Strategies by Small- scale Entrepreneurs in Malaysia
}

\author{
Siti Masayu Rosliah Abdul Rashid¹, Fatimah Hassan ${ }^{1}$ and Kurshiah \\ Ahmad $^{2}$ \\ ${ }^{1}$ Geography Section, School of Distance Education, Universiti Sains Malaysia \\ 11800 Minden, Penang, ${ }^{2}$ Post-Graduate Student, School of Distance Education, Universiti Sains \\ Malaysia, 11800 Minden, Penang \\ Email: masayurashid@usm.my
}

\begin{abstract}
The Covid-19 pandemic has forced many countries to impose travel restrictions and movement control orders. In Malaysia, for example, the small enterprise sector is one of the areas most affected by the movement control order (MCO). One problem that has affected this sector is the closure of support sectors, such as retail and transportation, which has left smaller traders unable to operate, leading to losses in income. However, small-scale entrepreneurs who adopted the digital business platform were not affected by the Covid-19 crisis. Therefore, it is crucial to study the extent of strategies implemented by small scale entrepreneurs to strengthen the new post Covid-19 business norms and help boost their digital business platform. This study involved 75 small-scale entrepreneurs conducting online businesses. The study represents perspectives from WhatsApp groups formed by small-scale entrepreneurs and Facebook social networking in Peninsular Malaysia. Findings show that all the respondents conducted businesses in digital form, and they had formulated various business strategies to navigate through the post Covid-19 business era.
\end{abstract}

Keywords: Covid-19, Small Businesses, Digital Business, Online Business, New Business Norms.

\section{Introduction/Background}

COVID-19 ('CO' stands for corona, 'VI' for virus, and 'D' for disease) is an infectious disease caused by a newly discovered virus. According to reports, by September 2020, almost 31 million people would have been diagnosed with Covid-19, and approximately 954,417 people would have died (WHO, 2020). This scenario has inevitably led to a global economic downturn (Cheng, 2020 \& UNDP, 2020). Most governments in Southeast Asia, such as Indonesia, Malaysia, Thailand, the Philippines and Singapore, have imposed emergency and quarantine orders to prevent the spread of Covid-19 (Fabil, Pazim \& Langgat, 2020). This situation affects financial closure activities as normal business activities cannot be carried out, social distancing is advocated, there is no physical relationship or contact between sellers and customers, and there is a disruption in the delivery of products (Ghani, 2020). 
INTERNATIONAL JOURNAL OF ACADEMIC RESEARCH IN BUSINESS AND SOCIAL SCIENCES Vol. 10, No. 9, 2020, E-ISSN: 2222-6990 @ 2020 HRMARS

This situation has resulted in a reduction in the workforce in all sectors of the economy and has caused a vast number of people to lose their jobs (Karabarg, 2020).

In Malaysia, the small enterprise sector is one of the sectors most directly affected by the movement control order (Azman, 2020). This circumstance not only occurs during economic recessions among business people but also inhibits the income earned by small-scale entrepreneurs, especially in rural areas. The economic impact of COVID-19 has had a significant impact on the country, especially Small and Medium-sized Enterprises (SMEs) sector as it is estimated that this group constitutes $98.5 \%$ of the total number of enterprises (Kuriakose, 2020). In order to overcome this issue, various strategies are required to support the difficulties faced by small-scale entrepreneurs affected by the Covid-19 pandemic.

One of the strategies suggested is to activate the role of ICT to enhance business growth. For example, helping rural entrepreneurs by strengthening the role of rural communities to become drivers of the digital economy (Zhou, Gao \& Chimhowu, 2020). Since ICT has a huge role to play in society, it is suitable as a platform for transforming society to utilise ICT as a catalyst for generating income for traders. In the face of a never-ending Covid-19 crisis, small-scale entrepreneurs need to continue transforming and innovating their business strategies to ensure that new post COVID-19 business norms are more proactive. Hence, this study intended to examine the extent to which strategies implemented by small-scale entrepreneurs help develop their participation in digital business ventures. Besides, the participation in digital business ventures is also expected to remain resilient to meet future challenges.

\section{Methodology}

The study adopted the quantitative approach to examine the strategies applied by small-scale entrepreneurs in their business ventures during the Covid-19 pandemic. Study samples consisted of selected small-scale entrepreneurs in Peninsular Malaysia who conduct online businesses using the social media as a business platform.

The study samples were selected through the purposive sampling method. Purposive sampling was chosen because this study had specific goals and characteristics that must be present in the samples; hence, only small-scale entrepreneurs running online businesses were selected. Besides, the Snowball Sampling method was also used to select small-scale entrepreneurs involved in online businesses through the Facebook social site.

This study was conducted from June 01,2020 to June 15, 2020. Since this study was conducted during the movement control order (MCO) period, an online survey was carried out whereby a personal Google Form link was given to respondents. A total of 75 respondents were involved in this study. 
INTERNATIONAL JOURNAL OF ACADEMIC RESEARCH IN BUSINESS AND SOCIAL SCIENCES Vol. 10, No. 9, 2020, E-ISSN: 2222-6990 (C) 2020 HRMARS

\section{Results/Preliminary results}

Profile of Respondents

Table 1: Profile of respondents

\begin{tabular}{|c|c|c|}
\hline Profile & Frequency (n) & Percentage (\%) \\
\hline \multicolumn{3}{|l|}{ Age } \\
\hline 21 to 30 & 19 & 25.3 \\
\hline 31 to 40 & 40 & 53.3 \\
\hline 41 to 50 & 11 & 14.7 \\
\hline 51 to 60 & 5 & 6.7 \\
\hline \multicolumn{3}{|l|}{ Sex } \\
\hline Male & 18 & 24.0 \\
\hline Female & 57 & 76.0 \\
\hline \multicolumn{3}{|l|}{ Level of education } \\
\hline First degree & 49 & 65.3 \\
\hline STPM & 7 & 9.3 \\
\hline SPM/SPMV & 18 & 24.0 \\
\hline SRP/PMR & 1 & 1.3 \\
\hline \multicolumn{3}{|l|}{ Type of business } \\
\hline Food business & 52 & 69.3 \\
\hline Service business & 7 & 9.3 \\
\hline Beauty and health products business & 5 & 6.7 \\
\hline Clothing business & 1 & 1.3 \\
\hline Other services & 10 & 1.3 \\
\hline \multicolumn{3}{|l|}{ Business Medium } \\
\hline Facebook & 28 & 37.3 \\
\hline WhatsApp & 4 & 5.3 \\
\hline Instagram & 2 & 2.7 \\
\hline Facebook \& WhatsApp & 19 & 25.3 \\
\hline Facebook \& Instagram & 9 & 12.0 \\
\hline All of the above & 12 & 16.0 \\
\hline Others & 1 & 1.3 \\
\hline \multicolumn{2}{|l|}{ Number of years involved in the } & 72.0 \\
\hline Less than 3 years & 19 & 25.3 \\
\hline 4 to 6 years & 2 & 2.7 \\
\hline 7 to 9 years & 3 & 4.0 \\
\hline 10 years and above & & \\
\hline \multicolumn{3}{|l|}{ Monthly income } \\
\hline RM1000 and below & 30 & 40.0 \\
\hline RM1001 to RM2000 & 24 & 32.0 \\
\hline RM2001 to RM3000 & 13 & 17.3 \\
\hline RM3001 to RM4000 & 3 & 4.0 \\
\hline RM4001 to RM5000 & 3 & 4.0 \\
\hline RM5001 and above & 2 & 2.7 \\
\hline
\end{tabular}

Source: Online survey, June 2020. 
INTERNATIONAL JOURNAL OF ACADEMIC RESEARCH IN BUSINESS AND SOCIAL SCIENCES Vol. 10, No. 9, 2020, E-ISSN: 2222-6990 @ 2020 HRMARS

According to Table 1, 53.5 per cent of respondents are in the 31 to 40 years age group, while 6.7 per cent ( 5 respondents) are in the age range of 51 to 60 years age group. In terms of gender, majority of respondents (57 respondents or 76.0 per cent) who participated in this survey were women compared to men (18 respondents or 24 per cent). Besides that, 49 (65.3 per cent) respondents possessed a First Degree, while 52 respondents (69.3 per cent) ran a food-based business.

28 respondents (37.3 per cent) used social media business links, like Facebook, as their primary choice of a social media site, in addition to other social sites, such as WhatsApp, Instagram and WeChat. As for the number of years running a business, majority of respondents were still new to the business. 51 respondents (72 per cent) had been in business for less than three years. Only three respondents (4.0 per cent) had been in business for ten years or more. From the monthly income profile, 30 respondents (40 per cent) earned an income of below RM1000, while two respondents (2.7 per cent) earned an income of RM5001 or more (highest income bracket).

\section{Post Covid-19 Business Strategies}

The Covid-19 pandemic is not over yet and it is difficult to anticipate when the situation will fully recover. Nevertheless, the affected communities, especially small enterprise owners, cannot standby without doing anything to generate their business income. They need to restructure their plans and strategies while adapting to new realities related to post Covid-19 business activities.

According to Figure 1, among the main strategies preferred by respondents ( 32 respondents or 42.67 per cent) was to further expand their existing business. Besides, 21 respondents ( 28 per cent) planned to change their business concept or operations. This strategy is quite effective because this is the most suitable time for traders to re-evaluate the form of business that has the greatest potential and provide lucrative returns. Moreover, 13 respondents (17.33 per cent) chose to introduce new products, while the remaining nine respondents (12 per cent) did not have any business strategy for the future. 
Figure 1: Post Covid-19 business strategies

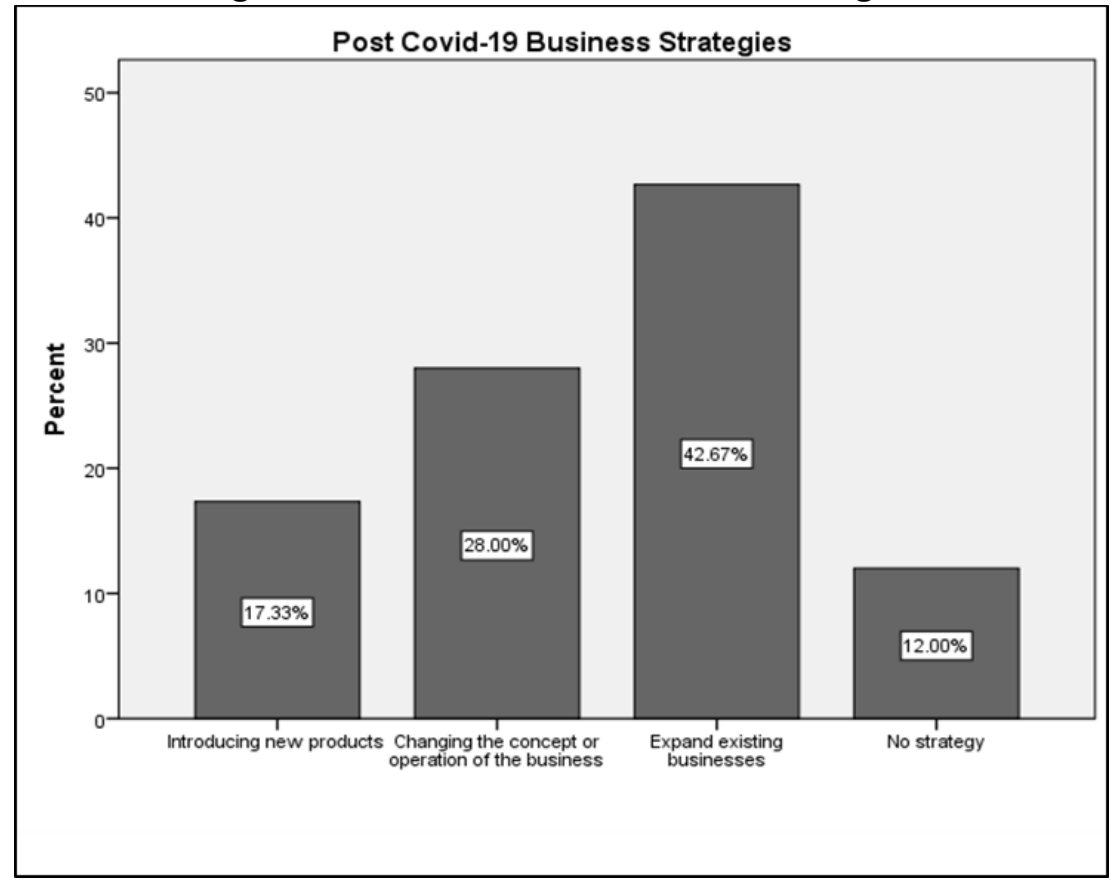

Source: Online survey, June 2020.

This study also examined the relationship between the period of running a business and respondents' business strategies for the future. The crosstabulation (Table 2) shows that there is a positive relationship between the two variables. Respondents' businesses that ran for less than a year were more focused on various types of strategies for the future compared to respondents who had long been involved in business activities. Majority of them (13 respondents) chose to further expand their existing businesses as a type of business strategy for the future. This situation is different from respondents who have been in business for seven or more years. Only four respondents wanted to expand their existing businesses. Findings about these two variables indicate that the choice of a post Covid-19 business strategy is influenced by the respondent's period of carrying out a business, as shown in Table 2 below.

Table 2: Crosstabulation showing the period of carrying out a business and post Covid-19 business strategies

\begin{tabular}{|c|c|c|c|c|c|}
\hline Strategies & $\begin{array}{c}\text { Introducing } \\
\text { new products }\end{array}$ & $\begin{array}{c}\text { Changing the } \\
\text { concepts or } \\
\text { operations of } \\
\text { the business }\end{array}$ & $\begin{array}{c}\text { Expand } \\
\text { existing } \\
\text { business }\end{array}$ & $\begin{array}{c}\text { No } \\
\text { strategy }\end{array}$ & Total \\
\hline Less than 1 year & 6 & 6 & 13 & 2 & 27 \\
\hline 1 to 3 years & 5 & 9 & 9 & 1 & 24 \\
\hline 4 to 6 years & 2 & 5 & 6 & 6 & 19 \\
\hline 7 to 9 years & 0 & 0 & 2 & 0 & 2 \\
\hline 10 years above & 0 & 1 & 2 & 0 & 3 \\
\hline
\end{tabular}

Source: Online survey, June 2020. 
INTERNATIONAL JOURNAL OF ACADEMIC RESEARCH IN BUSINESS AND SOCIAL SCIENCES Vol. 10, No. 9, 2020, E-ISSN: 2222-6990 @ 2020 HRMARS

The development of post Covid-19 businesses also shows that respondents were fully prepared to use the social media for their business activities. Results show that all 75 respondents (100.0 per cent) admitted that an online business venture could help the business grow as well as increase their income, as indicated in Table 3.

Table 3: Statement on online business

\begin{tabular}{|l|c|c|c|c|}
\hline \multirow{2}{*}{ Statement } & \multicolumn{2}{c|}{ Yes } & \multicolumn{2}{c|}{ No } \\
\cline { 2 - 5 } & Frequency & $\begin{array}{c}\text { Percentage } \\
\text { (\%) }\end{array}$ & Frequency & $\begin{array}{c}\text { Percentage } \\
\text { (\%) }\end{array}$ \\
\hline $\begin{array}{l}\text { Online business helps grow } \\
\text { your business }\end{array}$ & 75 & 100.0 & 0 & 0.0 \\
\hline $\begin{array}{l}\text { Online business helps } \\
\text { increase your income }\end{array}$ & 75 & 100.0 & 0 & 0.0 \\
\hline
\end{tabular}

Source: Online survey, June 2020.

\section{Conclusions}

In summary, it is evident that the COVID-19 pandemic affecting the nation has triggered a new business activity phenomenon. Hence, from a global perspective, the ravaging Covid-19 pandemic has to some extent changed the business structure as well as produce a society that needs to learn and explore new knowledge for continued sustenance through business activities. Although most governments have imposed social closures and various restrictions, online business activities can still be implemented and can further expand in the future.

Firstly, the problem lies with the community, which did not pay much attention to digital influence; however, this Covid-19 crisis has shown a tremendous growth in digital business ventures. In addition, this crisis also demonstrates that reliance on only one type of resource may not be enough to sustain business activities. Thus, regardless of the number of consumers, it is confirmed that online or digital businesses can be adopted as a new business model to meet the demand of consumer needs. The intention to use the digital business platform is consistent with the Technology Acceptance Model (TAM), which states that users are more likely to adopt a new technology and their technology usage behaviour is predicted by a person's perception about technology's usefulness. Strong empirical evidence suggests that usage of online or digital businesses can benefit small-scale entrepreneurs; thus, these types of ventures should be encouraged at all times and across the borderless world in spite of the COVID-19 pandemic.

In order to encourage small-scale entrepreneurs to participate in online business or digital business ventures, it is recommended that the government provide more funds, develop adequate infrastructure as well as train more trainers so that the opportunity, survivability, profitability and sustainability of their business activities can materialise.

\section{Acknowledgement}

We would like to thank Universiti Sains Malaysia (USM) for funding this project through Universiti Sains Malaysia's Short-Term Grant, grant number [304/PJJAUH/6315365]. 
INTERNATIONAL JOURNAL OF ACADEMIC RESEARCH IN BUSINESS AND SOCIAL SCIENCES

Vol. 10, No. 9, 2020, E-ISSN: 2222-6990 @ 2020 HRMARS

\section{References}

Azman, F. (2020). Adakah peniaga IKS Malaysia bersedia memasuki ekonomi digital? Astro Awani. 4 April 2020. http://www.astroawani.com/berita-malaysia/adakah-peniaga-iks-malaysiabersedia-memasuki-ekonomi-digital-236786

Cheng, C. (2020). COVID-19 in Malaysia: Economic Impacts \& Fiscal Responses. Institute of Strategic and International Studies (ISIS) Malaysia, ISIS- Policy Brief. Issue 1 (20), 1-20. https://www.isis.org.my/wp-content/uploads/2020/06/POLICY-BRIEF_COVID-19-inMalaysia.pdf.

Fabeil, N. F., Pazim, K. H., \& Langgat, J. (2020). The Impact of Covid-19 Pandemic Crisis on MicroEnterprises: Entrepreneurs' Perspective on Business Continuity and Recovery Strategy. Journal of Economics and Business, Vol.3 (2), 837-844.

Doi: 10.31014/aior.1992.03.02.241

Ghani, F. A. (2020). Impak psikologi akibat wabak Covid-19, Astro Awani, 14 March 2020, retrieved from

http://www.astroawani.com/berita-malaysia/impak-psikologi-akibat-wabak-covid-19233648.

Karabag, S. F. (2020). An unprecedented global crisis! the global, regional, national, political, economic and commercial impact of the coronavirus pandemic, Journal of Applied Economics and Business Research,10 (1), 1-6.

http://www.aebrjournal.org/uploads/6/6/2/2/6622240/joaebrmarch2020_1_6.pdf

Kuriakose, S. (2020). Reopening Malaysia's economy in a new normal. 7 May 2020. Published on East Asia \& Pacific on the Rise in World Bank Blogs. https://blogs.worldbank.org/eastasiapacific/reopening-malaysias-economy-new-normal.

UNDP - United Nations Development Program. (2020). The Social and Economic Impact of Covid-19 in the Asia-Pacific Region. Position Note Prepared by UNDP Regional Bureau for Asia and the Pacific. April 2020.

https://www.undp.org/content/undp/en/home/librarypage/crisis-prevention-andrecovery/the-social-and-economic-impact-of-covid-19-in-asia-pacific.html

World Health Organization - WHO. (2020). WHO Coronavirus Disease (COVID-19) Dashboard. 21 September 2020. https://covid19.who.int/

Zhou, Q., Gao, P., \& Chimhowu, A. (2019). ICTs in the transformation of rural enterprises in China: A multi-layer perspective. Technological Forecasting and Social Change, Vol 145. Pages 12-23. https://doi.org/10.1016/j.techfore.2019.04.026 